\title{
'Sons of Bengal' and the Absent Daughters: Gender, Performativity AND NATIONALISM IN BENGALI JUVENILE LiTERATURE
}

\author{
Stella ChitraleKHa BisWAS \\ Central University of Gujarat \\ stella.biswas876@gmail.com
}

Received: 14-10-2020

Accepted: 18-02-2021

\begin{abstract}
This article looks at the asymmetrical bifurcation of gender roles and performativity that is reflected palpably within Bengali juvenile literature of the twentieth century. These writings strove to venerate a cult of hypermasculinity through the portrayal of brave, assertive Bengali heroes who engaged in various escapades in distant lands or in the solving of mysteries and crimes, either alone or accompanied by male confidantes who remain completely devoted to them. This dominant cultural trope was consciously employed as a challenge to the imperial, racist stereotypes of the effeminate Bengali man who was imagined to be inferior to the virile, robust and intellectually superior Englishman. However, the role of women within such diegetic portrayals is liminal or conspicuously absent; female readers are conditioned to "wallow in the reflected glory of their heroes" (Mukherjee para. 13). This paper also looks into the politics of sexuality and nationalism involved within the celebration of male homosocial bonding over heteronormative relationships, thereby leading to the almost complete effacement of female agency.
\end{abstract}

KEYWORDS: Bengali juvenile literature; hypermasculinity; racist stereotypes; sexual politics; nationalism; male homosocial bonding; female agency

RESUMEN "Hijos de Bengala" y las hijas ausentes: género, performatividad y nacionalismo en la literatura juvenil bengalí

Este artículo analiza la bifurcación asimétrica de los roles de género y la performatividad que se refleja de manera palpable en el género de los thrillers de aventuras bengalíes. Estos escritos se esforzaron por venerar un culto a la hipermasculinidad a través de la representación de héroes bengalíes valientes y asertivos que participaban en variadas escapadas en tierras lejanas o en la resolución de misterios y crímenes, ya fuera solos o acompañados de confidentes masculinos que permanecen completamente dedicados a ellos. Este tropo cultural dominante se empleó conscientemente como un desafío a los estereotipos racistas e imperiales del hombre bengalí afeminado que se imaginaba como inferior al inglés viril, robusto e intelectualmente superior. Sin embargo, el papel de la mujer dentro de tales representaciones diegéticas es liminal o notoriamente ausente; las lectoras están condicionadas a "revolcarse en la gloria reflejada de sus héroes" (Mukherjee párr. 13). Los lectores masculinos, de hecho, son llamados a dejar de lado cualquier vínculo con indulgencias femeninas o menos firmes que los desviarían del camino de moldearse a sí mismos para ser los hijos ideales de su patria. Este artículo también explora las políticas sexuales que rigen la celebración del vínculo homosocial masculino por encima de las relaciones heteronormativas, lo que lleva a la eliminación casi completa de la agencialidad 
femenina. También son críticamente examinadas las implicaciones de estas nociones de identidad y roles socioculturales de género y la desexualización perpetrada a través de dicha literatura en el contexto de una división público-privada más amplia, con el creciente impulso de la cuestión de la mujer en Bengala en una era de ferviente nacionalismo.

PALABRAS CLAVE: thrillers de aventuras bengalíes; hipermasculinidad; estereotipos racistas; políticas sexuales; nacionalismo; vínculo homosocial masculino; agencialidad femenina

\section{Introduction}

The idea of gendering in children's literature has managed to stimulate considerable interest over the past few decades and juvenile literature in Bengal is no exception in this regard. The history of the latter goes back to its roots in the nineteenth century and the socio-cultural developments that spurred the region in the drive towards colonial modernity. Striving to free itself from the grip of a foreign monopoly, native juvenile literature in Bengal gradually started achieving increasing popularity, especially in the era of a nationalist awakening. The intervention of the Brahmo reformers in these pedagogical practices implicated the propagation of certain legitimized and morally sanitized ideologies on gender, identity, sexuality, values, ideals, etc. among the potential readers. Gendered discourses started infiltrating the realm of popular juvenile literature since the early traces of its advent and can be understood as deliberately influencing the formative consciousness of the young readers with a definite nationalist agenda as the era progressed. While writings specifically targeting a male readership championed the ideal of Bengali masculinity, it came to be understood that women had to remain content with derivative roles within the context of intellectual or physical quests that were celebrated in such diegetic spaces.

\section{Colonial Moorings of Bengali Juvenile Literature}

Bengali juvenile literature has come a long way since its origin at the initiatives taken by British Evangelicals and missionaries to educate the native masses and bring about a sort of reconstruction of Bengal within the colonial scenario. The nineteenth century witnessed juvenile literature in Bengal striving to free itself from the clutches of an imperial hegemony and establish itself as an independent genre in its own right. Apart from instructional and didactic books that contained the implicit propaganda consolidating the interests of the Empire, literature meant specifically for the leisure reading of children in the private domain of the home and the family went on to gain increasing popularity. The leisure literature's innovative approach of teaching children through entertaining means and the medium of the vernacular language had a greater appeal, leaving a lasting impression on the minds of the target 
readership. In fact, this type of literature flourished thanks to the efforts and patronage of the elite Brahmo intellectuals who had a definite agenda of moulding the children, especially the boys, to live up to certain ideals that would prove their competence in the struggle for emancipating their enslaved motherland. In general, the minds of juvenile readers from both sexes were impressed upon with consciously crafted ideologies on gender roles, identities, socio-cultural mores and sexuality.

The interest in adventure and the generic avenues apt for a fictive exploration of the same emerged within the field of Bengali juvenile literature in the mid nineteenth century itself, as it had been highly influenced by an already previously-thriving imperial interest for gaining knowledge about uncharted territories and reveling in thrilling quests. This was a time when extensive cartographic activities were in full swing in order to survey, scientifically understand and reorganize the hitherto undiscovered terrains of India as well as other colonies, and contribute to Britain's imperialist projects. Along with this was gradually established the tradition of imbibing a masculinist image of the robust, adventurous Englishman engaged in the expansion of the Empire, within the pedagogic paradigms of English juvenile literature. British periodicals for children and adolescents from the late Victorian period onwards had featured fictionalized pieces on adventurous exploits, biographies and stories of daring questers, robinsonades, etc. that actively sought to instill a sense of patriotic zeal and masculinist temperament within formative minds (Ferrall and Jackson, 2010: 9-10 and Kutzer, 2000: 14-15). With a surge in the market demand for such literature in the wake of the Education Act of 1870 as well as advancements in print capitalism and the growth of certain Evangelical influences in pedagogic practices, numerous such periodicals like the Children's Friend, Boys' Own Paper, Rovers of the Sea, Camps and Quarters, Union Jack, Sons of Britannia and others began to flourish, celebrating "initially Christian and later national ideals" (Ferrall and Jackson, 2000: 11).

Naturally enough, Bengali juvenile periodicals which drew upon their imperial predecessors considerably in their initial stages of development in the mid nineteenth century, thanks to the efforts of both the Baptist Evangelicals of Serampore Mission Press and the native reformists, began incorporating pieces on adventure, sports, travel exploits, etc. that were becoming an increasingly popular aspect of the target readers' interest. These Bengali periodicals, particularly those issues published between 1904-1939, manifested a keen eagerness to include pieces on both foreign and native landscapes as well as cultural histories. They extolled not only the enchanting geographies of distant countries but also specifically emphasized the ideas 
of modernity and advancement, particularly the accomplishments of the youth in the nationbuilding process (Sen, 2004: n.p.) The emphasis upon outdoor activities, physical exertion, maintenance of bodily discipline, etc. is another discursive trait that first emerged in Bengali juvenile literature through these popular periodicals for children which emphasized the merits of these pursuits in various serialized issues. Periodicals namely Bibidhartho Sangraha (Miscellany, ) Abodh-Bandhu (The Innocents' Friend, 1866), Jyotiringan (The Firefly, 1869), Balak-Bandhu (The Child's Friend, 1878), Sakha (The Friend, 1883), Balak (The Child, 1885), Sakha O Sathi (The Friend and Companion, 1894), Mukul (The Bud, 1895), etc. featured not only travel accounts but also accounts of the exploits of various Bengali personalities that glorified their fiery patriotism. The idea of the swadesh or the homeland was inevitably linked to the epitomizing of Bengali heroism and racial pride, thereby implicitly subverting the politics of "cultural antagonisms" (Gangopadhyay, 2012: 235).

These juvenile periodicals also published various articles that emphasized the necessity of male readers to indulge in sports, physical activities and other adventurous exploits in order to nurture their physical virility, mettle and capability that would be an essential requisite within the larger project of emancipating their enslaved motherland. Coupled with attractive illustrations, sketches, maps and photographs of important personages (especially Bengali travelers or native football and cricket teams), these articles sought to both entertain and instruct the young readers in a manner that would "...counter the colonial stereotypes of civilized and uncivilized, rational and irrational, manly and effeminate" (Biswas, 2019: 6), providing for them a model of idealized native childhood to be followed. The pieces focusing on the dissemination of historical and geographical knowledge about the Indian subcontinent itself proved particularly telling in manifesting a sense of patriotic pride and interest regarding the wealth of the nation's rich socio-cultural diversity. Often, the unearthing of alternate local or folk histories were made possible through these exploratory writings that attempted to instill a sense of appreciation for them among the readers in the face of hegemonic imperial discourses. These periodicals were not only limited to such factual articles but also went on to include

accounts and stories...published, of adventures and hunting expeditions by daring Bengali men who were portrayed as braving several odds, travelling to faraway, distant, unknown lands, battling against wild beasts, etc. thereby presenting the model of the 'manly' Bengali man who remained dauntless, composed and unperturbed in the face of perils or danger and emerged victorious out of sheer courage, determination, command over self and physical virility (Biswas, 2019: 7). 
Thus, an idea of a glorious ancient past of Bharat-mata was evoked alongside repetitive reminders of the worthy heroes she harboured within her bosom in order to implicitly engender a spark of active revolutionary nationalism that would serve as an antidote to the crisis, cleavages and frustrations brought about by the tensions of colonial rule.

The early adventure story and detective fiction genres in Bengal, borrowing this trait, pivoted upon the cult of the daring, intelligent, sharp-minded and physically capable native hero or sleuth venturing forth on solving mysteries, crimes or on other adventures, accompanied by a strictly male companionship, with no trace whatsoever of any female figure playing any active part within the highly gendered world of such a narrative. Even if female figures appeared within the diegetic space of these narratives, they were usually relegated to very insignificant, liminal roles which left no lasting impression upon the minds of the juvenile readers. This was coupled with the appeal for adopting a progressive outlook like the Western people, underlining the necessity to free the mind from regressive, backward superstitions and enlighten oneself in logical principles that would in turn contribute to modernity and socio-cultural development. The writers envisioned such narratives to cater to the needs of a native readership who were consciously aware of their traditional roots as well as of the necessity for a scientific, rationalized reorientation of their mindsets. The performative aspects of gender and asexuality incorporated within the diegetic space of this literature and its significance within an era of militant nationalism, inevitably led to the cultivation of differential notions of agency within the minds of the target readership. The first stirrings of such an adult-monitored ideal in the realm of the Bengali adventure and detective literature proper can be traced back to Bibhutibhushan Bandopadhyay's 1937 novel, Chander Pahar (which translates as 'The Mountain on the Moon'). This novel inaugurated a trend that was to be followed by the successive generation of Bengali speculative fiction writers as well.

\section{A Masculinist Domain}

In the chapter titled 'Romance and the Boys' Story' in their book Juvenile Literature and British Society, 1850-1950, Charles Ferrall and Anna Jackson talk about the coupling of imaginary, fantastic details with realistic elements in the English adventure stories: “...these authors ballast fantasy with the lead of realistic detail. Descriptions of exotic landscapes, amazing adventures, and fierce battles insist on their factualness or veracity, sometimes to the point of fetish" (Ferrall \& Jackson, 2010: 42). The idea of the British boy participating in dangerous escapades and adventures in exotic, unfamiliar worlds is presented as a rite of 
passage which he must go through in order to better realize the world of adult responsibilities and his vocation for the public good back home. John M. MacKenzie, Gillian Avery, J.S. Bratton, Jeffrey Richards and others have talked about the proliferation of the public school tales in popular Victorian juvenile periodicals that invoked the cult of British masculinity and associated imperialist aspirations (Gangopadhyay, 2012: 219). Thus, this pedagogical exercise can be understood as a deliberate instruction of the child readers in the masculinist ideologies of the Empire that sought to perpetuate its hegemonic control through a celebration of heroes who are "gendered as fully male" (Ferrall \& Jackson, 2010: 48). This necessitated an "expulsion from the feminine constituting his masculinity" (ibid) by "being licked into manliness" (ibid: 50) in the course of various fruitful adventures.

Such a stance was eagerly taken up by several Bengali intellectuals including Gnanadanandini Devi, Prasannamayee Devi, Abala Basu, Swami Vivekananda, Rabindranath Tagore, Acharya Prafulla Chandra Sen, and others who were inspired by a model of "youth, masculinity and fitness" (Bratton, 82-83) propagated by the imperial counterparts. Another palpable instance of this can be found in the Foreword to Harendra K. Sarkar's 1923 book titled Heroes of Bengal. Here, he makes the declaration that, "The Bengali boy is naturally eager to know something of the great heroes of the land...A coward is a bad citizen" (Sarkar, 1923: 1) and goes on to glorify the "great prospective benefit" (ibid) that would result "if we could rouse a martial spirit and true patriotism in our boys. Cosmopolitanism may be the ideal for all education, but its most practical aim is to rouse in one a sense of national importance" (ibid). Sarkar was actually referring to an alliance between the native nationalist interests and a sense of "healthy loyalty" (Sarkar, 1923: 1) to the British government that would result from a greater exposure of the Bengali child's mind to the lives of great, historical native heroes who "all were sons of Bengal and did their duty by her" (ibid). This reference highlights the ingrained desire within the mindsets of the Bengali intellectuals to inspire and motivate the juvenile readership towards a definite socio-cultural ideology. In fact, throughout the course of the entire book, Sarkar keeps dwelling upon the trope of the manly, militant Bengali man who possessed great physical and intellectual prowess, fortitude and command over himself. The lives of seventeen Bengali heroes that he celebrates in his work come across as a validation that he puts forth for his claim that "In no period of the history of Bengal was she wanting in the heroic spirit" (Sarkar, 1923: 98) and that "Heroes are not born for the hearth, but for the field of action" (ibid: 10). 
This line of thought reflects very strongly upon the genre of Bengali adventure-mystery stories (though speculative) that emerged in an era when Bengal was readily embracing a spirit of nationalistic fervor. Coupled with this was the infusion of a scientific temperament within the narrative space of such literature so as to reconcile the demands of both "modernity and tradition" ("Culture...", 2019: para. 8). This entailed the perpetuation of a "cult of "masculinity"' (Gangopadhyay, 2012: 182) through the portrayal of dauntless, assertive native heroes who would pose a direct challenge to the imperial stereotypes of the dominant colonizer and the subservient colonized. It also sought to directly address and counter the stereotypical image of the 'effeminate' Bengali man which had been legitimized through the politics of representing the self within the imperial imagination (Sinha, 1995: 21 and Chowdhury, 1998: 2). In the context of such a socio-cultural and literary backdrop, the discussion in this article will turn to focus specifically upon two of Hemendra Kumar Roy's popular and well-known adventure novels, Jaker Dhan ('The Cursed Treasure') which was published in 1924, its more popular sequel, Abar Jaker Dhan ('The Cursed Treasure Once Again') which came out in 1933 and two of Satyajit Ray's famed detective series Hatyapuri ('The House of Death') and Kailashey Kelengkari ('A Problem in Kailash'). Both of Roy's novels feature the Kumar-Bimal duo of brave Bengali youths travelling to unknown, faraway lands for the sheer thrill of adventure that also had some greater social purpose associated with it, and they went on to become so popular among the juvenile readership that the author wrote several other novels featuring the heroic exploits of the same duo. Initially published in serialized issues of the Moucak ('Honeycomb') magazine, a popular juvenile periodical in the twentieth century, these stories later went on to be compiled in volumes in the form of the adventure novel proper. On the other hand, both of Ray's aforementioned novels were published as serialized issues in 1974 and 1979, respectively in Sandesh ('Sweetmeat'), the family magazine of the author and later released in book form by Ananda Publishers. Ray's novels center around the exploits of the trio, Pradosh C. Mitter (Feluda, the detective), Topshe (his cousin and assistant) and Lalmohan Babu (alias Jatayu) in solving complicated crimes at various spatial locations across the country. Unparalleled in popularity, the Feluda series in Bengali detective fiction has achieved the cult status as that of Sherlock Holmes in British crime fiction.

\section{The Rise of the Assertive Bengali Hero}


In the Preface to Abar Jaker Dhan, Roy himself clearly states his purpose of venturing forth in the world of adventure and mystery novel writing. He expresses his sense of pride in accomplishing the much needed task of coming up with a kind of writing that compensated for a significant lack in the Bengali literary canon that had existed till then. He proclaims that boys had a penchant for adventure and that the prime motive of his writing was to satiate the appetite for it among his juvenile readers. He expresses his desire to inspire Bengali boys to strengthen not only their physique but also their temperament, so that despite their love for their motherland, their spirits will relentlessly expand across universal bounds, so that their source of pleasure may develop unhesitatingly even in the face of danger and death; so that their lives may be moulded by the steadfast determination they might be able to garner in various situational perils. He opines in favour of the "living book" (Roy, 2001a: 4), one which frees the juvenile mind from the narrow stringencies of didactic schoolbooks and opens up an entirely new world for it to expand and truly make men out of the readers. Straying from the age-old, traditional perspective, he desires Bengali boys to be uninhibitedly energetic, adventure-seeking, to be nurtured in the lap of danger and challenges, and to achieve glory in heroism. This is the strain that runs through all of the Kumar-Bimal adventure novels, in which he promises to satisfy the requirements of his adventurous and thrill-seeking readership.

In the case of the afore-mentioned Kumar-Bimal novels, Roy chooses to portray a varied canvas of narrative settings in order to elaborately paint the adventurous exploits of his two young adult heroes. While Jaker Dhan is set in the dense, almost impenetrable wilderness of Assam (Khasi Hills, in particular) and its forest-clad hilly terrain, the sequel Abar Jaker Dhan plots its action against the difficult topography of Africa and its dense, predator-infested jungles. Interestingly enough, as the titles suggest in both books the main motivation for adventure is the search for a hidden treasure; however, it is the heroes' irrepressible love for adventure and idealistic notions about danger and death rather than sheer materialistic greed that lures them on their various arduous quests. This vantage point of the writer is particularly important in order to group his heroes into a certain consciously crafted category of the ideal, nationalist-minded Bengali hero whose vocation in life is selfless service to the nation and humanity at large, even at the cost of his own life and safety.

In her blog article titled 'Bengali Adventure Stories', Rohini Mitra discusses the oeuvre of Hemendra Kumar Roy's adventure fiction, saying that “...Hemendrakumar had stated that the purpose of his writing a book like Jaker Dhan was to empower Bengali boys not just physically but mentally too. A close reading of both books reveals how their author sought to infuse 190 Indi@logs, Vol 8 2021, pp 183-200, ISSN 2339-8523 
nationalism in the minds of the young readers" (Mitra, 2010: para. 2). In both the aforementioned novels too, the Kumar-Bimal duo come across as epitomes of courage, firmness and unwavering loyalty towards their motherland. In fact, the character of Bimal is portrayed in a more favourable light in comparison to that of Kumar, the former unrelentingly striving to inspire and motivate the latter in times of crisis. In one of the very early chapters of Jaker Dhan, Bimal declares in a very impressive speech that it was much better to die a hero in action than a coward in bed and that it was shameful to identify oneself with the so-called 'good boys' possessing timidity and meekness of spirit. He goes on to say that these were the people who remained subservient under the brunt of foreign domination, giving up their lives like emasculated slaves and bringing ignominy to their own nation and native community. According to him, the great civilizations of the world consisted of people who had the zeal to keep their heads high, defying the possibilities of danger and death (Roy, 2001a: 20).

It is interesting to note that there are several types of masculinities that collide and also complement each other within the fictive requirements of the novels. From the urban-bred, smug, middle-class gentlemen with meek temperaments to socially lower-ranked servants, timid village simpletons, villainous antisocial criminals, 'uncivilized' and barbaric tribesmen of Africa, and so on, various socio-political constructs can be found abounding the purview of Roy's works. However, the discursive implications of each type are carefully maneuvered to ultimately serve the end of championing one specific trope- that of the masculinist Hindu body politic that was being effectively championed by the nationalist intelligentsia through various discursive practices. Fitting perfectly into this trope, Bimal is the one who keeps on spurring encouragement in the hearts of his comrades to carry forth on their perilous, often tending to be even fatal, journeys, battling odds and fighting off mean-spirited, murderous adversaries and achieving not only glory for themselves but also in turn setting examples for the young generation of contemporary Bengal. In chapter eleven of Abar Jakher Dhan, Kumar reiterates an account of Bimal's charisma, alluding to several adventures that they had embarked upon together - from the adversities in the jungles of Assam, to the extreme hazards faced during an apocalyptic alien invasion and their subsequent abduction to Mars or the dystopic encounters in the phantasmogoric wilderness of Maynamati. Bimal embodies the mythic-historical ideals of the exemplary Bengali hero who was envisioned as possessing unparalleled fortitude, composure, steadfastness and not only physical strength but also immense command over self and situation, especially in times of crisis. 
This emphasis upon physical prowess and the importance of proving one's masculinity and competence is a strain which was not uncommon within the then Bengali socio-cultural scenario and went on to be carried over even in the latter half of the twentieth century. In this light, the prototype of the hyper-masculine, professional detective solving crimes and mysteries with his unmatched intellect, zest and adventurous spirit expanded to embrace the tenets of cosmopolitanism through the dexterous treatment received at the hands of Satyajit Ray. Ray's contributions to the realm of Bengali juvenile literature are immense, especially with his creation of the memorable 'Feluda' series which have remained the cornerstone of ageless critical debates. The cult-figure of the extremely analytically-minded detective became an integral part of popular Bengali juvenile literature, especially influencing the fiction produced in the post-independence years in Bengal. Ray did not begin writing with any definite agenda in mind; he merely wanted to try his hand at a novel arena of writing that would appear in serialized form in his edited magazine, Sandesh. After the first publications between 1965-66, the overwhelmingly positive reception of his work propelled Ray towards developing the legendary heroic figure of 'Feluda' during a time when Bengali detective fiction had almost reached an impasse in terms of innovation.

Feluda or Pradosh C. Mitter fits into the trope of the quintessential Bengali dada- another cult that had emerged within the Bengali socio-cultural scenario of the mid twentieth century, standing for a universal elder brother who becomes the role model of the young and mentors them without any sort of overindulgence. An affectionate older brother and a strict disciplinarian at the same time, Feluda embodies a cosmopolitan charisma despite his traditional roots and is "enlightened in a more European way. Feluda is that Bengali which all Bengalis want to be" (Chattopadhyay, 2017: n.p.). His character evolves to become timeless, not restricted to any particular period and Ray has managed to wonderfully conjure up the image of the late twentieth century middle-class, educated Bengali home through the plots of these stories. The obvious influence of Sherlock Holmes upon Feluda's characterization is palpably felt throughout, from "the tall aquiline features of the protagonist and his method of deduction to the chronicling of his adventures by his ever-present understudy" (Chattopadhyay, 2017: n.p.). Sayandeb Chowdhury perceives the functioning of the Feluda plots upon certain clearly demarcated generic and critical conceptualizations:

an easily identifiable cultural sphere of activity; a palpable fondness for the adventurism of the boy-thriller genre; a careful calibration of crime and the self-imposed limits displayed within the morally efficacious collective of characters; a kindred compatibility sustained through Feluda's unageing youth and brilliance; the reinforcement of the private-eye as the human 
interventionist in the spoils of crime as against the purported governmentality of the police; and finally, the censored, sexless charms of truth-bearing juvenilia (Chowdhury, 2015: 115-116).

These carefully attuned tenets inevitably develop certain problematic patterns of gender disparity and a conscious cultural conditioning to exclude the female subject from any display of active agency.

Critics have deduced from Ray's rich oeuvre that he had a singular pedagogical preoccupation with "young male children as agents of uprightness and innocence" (Chowdhury 114). The cautious crafting of Feluda as an epitome of iconic Bengali masculinity reveling in a phallocentric world of activity is obviously linked to the creation of a universe bereft of natural curiosity for sexual matters. In both Hatyapuri and Kailashey Kelengkari, Feluda customarily reinforces his image as the bhadralok detective who undertakes travel, breathless adventure and a brilliant display of physical and analytical prowess (using his magajastra or 'mind weapon') to solve crimes in various parts of the Indian subcontinent. Interestingly enough, both the novels implicitly contain patriotic ideologies such as the return of ancient Indian manuscripts to their rightful owner in Hatyapuri and the prevention of illegal smuggling of ancient Indian sculptures in Kailashey Kelengkari can be read in a political light. Despite having been deliberately shielded from the ongoing Leftist politics of 1970s Bengal, these undeniable elements of nationalism are subtly ingrained within the plots of the two aforementioned novels. Feluda is the discursive manifestation of the flawless professional detective with "intuition, physical fitness, knowledge and general awareness, power of observation and interests in games and sports and overall smartness" (Ghosh, 2016: 126). In Kailashey Kelengkari particularly, Feluda displays immense martial skills in the course of the dramatic, action-filled encounters with the anti-nationalist smugglers who are robbing the nation of its heritage. Likewise, in Hatyapuri Feluda embarks on thrilling chases of the villainous smugglers of ancient manuscripts, once even at the cost of his life, to emerge victorious in the end. These two novels portray the Bengali hero as a delightful mixture of the nuances of both the armchair intellectual and the agile adventurer.

Ray appears to be intent on foregrounding Feluda's cosmopolitan masculinity in juxtaposition with the teenager Topshe and the middle-aged Lalmohan Babu. Topshe is the mesmerized narrator of these stories, occupying an unquestioning role as the charismatic detective's sidekick, while Lalmohan Babu is more than often a humorous ally and foil in their many adventures together. In both Hatyapuri and Kailashey Kelengkari, Feluda is the one who actively intercepts the conspiracies of the criminals and solves the cases albeit with the 
assistance of his companions who are eager to aid him in his endeavours. Feluda smokes Charminar cigarettes, has a proclivity towards the finer aspects of life, socializes with people extensively, has immense knowledge about places and cultures, dons disguises, often uses his sidekicks as baits in luring the criminals and also keeps night vigils upon the suspects at times - being the primary agent in the entire investigation process. "...[T]hrough the articulation of buddhibal in contrast with bahubal ${ }^{1}$ that negotiates with the hegemonic national-masculine" (Chattopadhyay, 2011: 265), he fits perfectly into the archetype of the cosmopolitan male wanderer that is engendered upon the crucial conceptualization of the aspirations of late twentieth century genteel, Bengali masculine subjectivity.

\section{Absence of Adventurous Females}

It is very interesting to note that throughout the course of their adventures, the male heroes are accompanied every time by an all-male camaraderie. The Jayanta-Manik novels portray the duo engaged in escapades in the sole company of their faithfully fierce dog, Bagha and their devoted servant, Ramhari. They have encounters with several other characters who are all predominantly male, with a handful of liminal, inconspicuous female figures appearing within the diegetic space of the narratives. In this all-male world, women have no active role to play or any agency in shaping the actions or the destinies of the male protagonists. In both Jaker Dhan and Abar Jaker Dhan, respectively the only women that the readers come across are either the middle-aged, very traditional character of the Bengali housewife in Kumar's mother who is bound within domestic concerns, having absolutely no knowledge of the macrocosmic space of adventure in the world outside, or anonymous, homogeneously grouped African tribal women who have no role whatsoever in the plot or the action. The conspicuously negligible presence accorded to women within the diegetic space of Roy's adventure fiction speaks volumes about the male-centric discourses that shaped the ideological and pedagogical concerns of the writers of Bengali juvenile literature and legitimized the effacement of overt female agency in the visions of nation-building. The physical journeys that the male heroes embark upon can be viewed in the light of metaphorical journeys that they undertake in order to undergo an unsaid rite of passage that would result in their evolution as complete men. This

\footnotetext{
1 The notions of the 'buddhibal' and the 'bahubal' can be understood within the context of the complex negotiations that have been a part of formulating ideas surrounding Bengali masculinity since the colonial times. While nineteenth century discourses specifically focused upon the trope of the virile, physically strong Bengali male or the 'bahubal' to counter racist stereotypes, the twentieth century turn towards cosmopolitanism in native ideologies heralded the concept of the 'buddhibal'. Thus, what emerges is a transition from a masculinist national body-politic towards a more nuanced awareness of the refinement and sophistication of the Bengali bhadralok. 194

Indi@logs, Vol 8 2021,pp 183-200, ISSN 2339-8523
} 
is why it is necessary for them to be extricated from the sheltered space of their home and family wherein lie the feminine or emasculating presence of their mothers or other female relatives, and to be placed amidst unfamiliar, seldom traversed, dangerous territories that would aid in the shaping of their manliness.

One might detect certain recurrent descriptions of Nature in the narrative space of Roy's novels in highly picturesque terms, comparing it to a mother bestowing its nurturing care upon mankind and rejuvenating the spirits of the male heroes who are its brave sons. However, this cannot be completely understated merely "as a 'feminine' Indian attitude towards Nature" (Chando Roy, 2018: 19) but should rather be regarded as a conscious attempt on the part of the writers to foster a sense of communal and national pride through developing a sympathetic understanding of the natural wealth of the country. This is a pertinent reason that accounts for the allegorical glorification of the native hero leaving the protective influence of the birth mother and stepping into the unfamiliar world outside in order to prove himself as a devoted son towards the mother-nation. For instance, in chapter five of Abar Jaker Dhan, Bimal gives yet another inspiring speech on the necessity for harnessing a deep attachment towards one's motherland, which is one of the prime sources of nurture and replenishment in one's life. He voices his patriotic sentiments by emphatically proclaiming that one's mother-nation ought to be regarded as much greater than one's human mother. Sailing on a ship towards a foreign continent for yet another thrilling adventure, Bimal expresses his love and loyalty for his motherland whom he venerates as an eternal source of comfort and sustenance, transcending mortal relationships and emotions (Roy, 2001a: 107).

Similarly, Satyajit Ray had one strong principle in mind while composing the 'Feluda' stories - that he would permit nothing illicit or morally dubious to feature at all in his work. The fact that he was consciously writing with a definitive strategy of catering to the demands of a juvenile readership makes his efforts to create a sanitized version of a Bengali whodunnit devoid of violence or sexual references, even more telling. This is precisely the reason accounted for the absence or liminal presence of women in Ray's Feluda narratives. And he does it so deftly that the lack of women characters often become inconspicuous to the lay readers' eyes, only to be realized with a critical afterthought. The engrossing world of derringdo featuring the masterly presence and feats of the Bengali detective and his all-male companionship very often elide any active participation on the part of women. Seven of around thirty four stories written revolving around Feluda namely, Chhinnamastar Abhishaap ('The Curse of the Goddess'), Napoleaner Chithi ('Napolean's Letter'), Amber Sen Antardhayn 
Rahasya ('The Disappearance of Amber Sen'), Bosepukurey Khunkharapi ('The Acharya Murder Case'), Jahangirer Swarnamudra ('The Gold Coins of Jahangir'), Shakuntalar Kantha Haar ('Shakuntala's Necklace') and Dr. Munshir Diary ('Dr. Munshi's Diary') have been understood as admitting a female presence; the rest completely curb the scope of female agency or performance of illustrative feats for personal growth or socio-cultural development. Barring a handful of exceptions, the women characters in Ray's world inevitably slip into the bounds of domesticity, ultimately proving to be lacklustre and unimpressionable as compared to their male counterparts.

Sayandeb Chowdhury reads Ray's Feluda novels as containing a "customary, almost dogged insistence on a world under-populated by women as long as that world belongs to children and young boys" (Chowdhury, 2015: 124). Feluda, unlike many other legendary detectives in the Bengali literary canon, neither possesses a love interest nor has any emotional or sexual attachment to a subject from the opposite sex. Similarly, Topshe is cast in the light of a precocious young boy who is blissfully unaware of the natural curiosities that arise during adolescence. Even Lalmohan Babu, a confirmed old bachelor, remains beyond all of these sexual and familial ties that Ray intended to leave out of the world of Feluda, possibly owing to his own Brahmo inclinations that had a puritanic attitude towards the female subject. While Hatyapuri completely excludes women from the entire plot structure, Kailashey Kelengkari has only one female character, the heroine Roopa who remains peripheral to the main plot action despite having discovered a dead body. In fact, Ray himself saw the presence of female agency in his fictive world as a "structural problem" (Chowdhury, 2015: 125) that would undermine the incorruptible potency of the males through libidinal complications. In this context, Sayandeb Chowdhury poignantly remarks:

If there is a structure at all, it is the structure of inheritance in which the women do not fit easily. Ray's project of locating a new usefulness for adolescent fiction is restored by excluding women as naturally synonymous with the erotic and hence the phobic. They are absolved of only potential criminality (except one), guilt, or reparation only because they are absorbed and co-opted into the plenipotentiary of the same/similar bhadrolok fatherly hegemon (Chowdhury, 2015: 125).

Against this backdrop, the repeated portrayals of male homosocial bonding in the relationships between the hero and his assistants can be looked at as an essential requisite within the highly gendered world of adventure, effectively obliterating any prevailing sense of anxiety over sexuality or carnal influences that could have been a possibility within heterosexual relationships (Mukherjee, 2018: para. 10). In fact, this idea was linked to the notions of celibacy, discipline and self-control in young men that became celebrated in the era of militant 196 Indi@logs, Vol 8 2021, pp 183-200, ISSN 2339-8523 
nationalism, something which sanctioned the ideal of resisting erotic or fleshly temptations in order to remain steadfast in service towards one's motherland. From battling mortal enemies, nomads and fierce tigers in the forests of Khasi hills to overpowering huge wild beasts, combatant indigenous tribes of Africa and even an army of mummies as well as an unseen enemy known as yaksha (akin to the concept of demons), it is only an all-male companionship that participates in all the sensational conquests depicted in Roy's works, thereby displaying not only the men's physical strength and vitality but also their intelligence, strategic skills and firmness of will. Similarly, the desexualized detective-hero in Ray's works is accompanied in his brain-riddling cases to various parts of the subcontinent from the beaches of Puri, Orissa to the temple-adorned hills of Ellora with an equally asexual teenager (who can be seen in the light of an almost prelapsarian state of innocence) and a middle-aged bachelor. As a product of colonial modernity and a newly forging notion of cosmopolitan masculinity, Feluda and his magajastra remain a crucial manifestation of the "aesthetic-political programming" (Chowdhury, 2015: 127) that lay behind the creation of ideal native childhood in Bengal. This cult of hypermasculinity carefully diminished the agency of the female characters, even to the point of complete effacement within the diegetic framework of adventure narratives.

It has to be kept in mind that the target readership of these adventure and detective novels was comprised of children and adolescents, even young adults from both sexes, though the intention of the writers was clearly to forge an idealized concept of Bengali boyhood that would, in turn, subvert and rectify the stereotypical notions of the effeminate Bengali man which had lingered long within the imperial imagination (Sinha, 1995: 21; Chowdhury, 1998: 2). Although Bengali juvenile literature "created a common intellectual and emotional 'space' for boys and girls for the first time in Bengali society" (Chando Roy, 2018: 26), these novels conditioned their readers to understand that while boys had the freedom to participate in such intellectual or physical quests, girls had to remain content through being typecast as the weaker, ineffectual sex and only "wallow in the reflected glory of their male heroes" (Mukherjee, 2018: para. 16). The physical ideal of femininity that had been in vogue in Western juvenile literature in the form of the girls' school stories, the adventure novels for girls, the Girl Guides stories and even the robinsonades for girls (Smith, 2011: 3-5) remained absent within the Bengali socio-cultural scenario. Despite the woman question in Bengal having reached its zenith of reform in the nineteenth century itself and female education having acquired considerable momentum by then, the ideas of spatial mobility and physical activity still met with disapproval from the conservationist mindset of traditional Bengali society (Bagchi, 1993: 2214). 


\section{Conclusion}

While readers shared the common, imagined identity of being the future inheritors of their nation, there still remained differential notions of agency, identity, performativity and perspectives on nationalism through the propagation of an asymmetrical bifurcation of gender roles within the diegetic space of adventure and detective narratives. This discrepancy "entailed the celebration of masculine standards of physical and intellectual prowess while subtly excluding the direct participation of females" (Biswas, 2019: 12). This crucially influenced "not only the patriarchal notions surrounding the participation of women in active nationalism further on in the twentieth century but have also spurred the endless, complex debates ensuing in the years to come, on the agency and socio-political subjectivity of women" (Biswas, 2019: 12). In studying Bengali juvenile literature through such theoretical premises, it can be concluded that the world of romantic adventure cannot be simply understated as a fantastic substitution with the world of prosaic reality. Rather, it comes across as an extremely subversive domain which problematizes and politicizes certain crucial ideologies on race, nationhood and gender, that in turn have significant socio-cultural impacts upon the highly impressionable consciousness of the juvenile readership. The portrayal of brave, strong, selfsacrificing, de-sexualized and resolute heroes in contrast to the absence of equivalent idealistic heroines have undoubtably left an indelible impression of "alterity and exclusion" (Mukherjee, 2018: para. 13) on the minds of the readers across generations, propagating and even legitimizing uneven dynamics of power within gender roles and performativity in both the public and the private spheres.

\section{WORKS CITED}

\section{Bengali Children's Periodicals (Archival Sources)}

(1869-1873). Jyotiringan, Hiteshranjan Sanyal Memorial Archive, CSSSC Library, Kolkata.

DEVI, GNANADANANDINI, editor (1885). Balak, Rare Book Division, The National Library, Kolkata.

GHOSH, JOGENDRANATH, editor (1866-1869). Abodh-bandhu, Hiteshranjan Sanyal Memorial Archive, CSSSC Library, Kolkata.

RAY, BHUBANMOHAN, editor (1894). Sakha O Sathi, Rare Book Collections, Bangiya Sahitya Parishad Library, Kolkata. 
SEN, BRAHMANANDA KESHAB CHANDRA, editor (1878-1891). Balak-bandhu, Rare Book Division, The National Library, Kolkata.

SEN, PRAMADCHARAN, editor (1883-1892). Sakha, Hiteshranjan Sanyal Memorial Archive, CSSSC Library, Kolkata.

SHASTRI, SHIBNATH AND HEMCHANDRA SARKAR, editors (1895-1899). Mukul, Rare Book Division, The National Library, Kolkata.

\section{Print and Web Sources}

BAGCHI, JASODHARA (1993). "Socialising the Girl Child in Colonial Bengal", Economic and Political Weekly, Vol. 28, No. 41, 2214-2219. $<$ http://www.jstor.org/stable/4400259> accessed 7 March 2019.

BANDOPADHYAY, SIBAJI (2007). Bangla Sishu Sahityer Choto Meyera, Kolkata: Gangchil.

BASU, BANI (comp) (1924). Bāmlā Śiśu Sāhitya Granthapaňjī (A Bibliography of Bengali Books for Children and Young Adults), Kolkata: Bangiya Granthagar Parishad.

BISWAS, STELLA CHITRALEKHA (2019). "A Gendered Space: A Critical Study of Juvenile Periodicals in Colonial Bengal". National Conference on Feminist Research Approaches to Gender Studies, Chennai, India. Unpublished conference paper. University of Madras, Chennai, 2019.

CHATTOPADHYAY, SAAYAN (2011). "Bengali Masculinity and the National-Masculine: Some Conjectures for Interpretation”, South Asia Research, Vol. 31, No. 3, 265-279. https://doi.org/10.1177/026272801103100305 accessed 6 January 2021.

CHATTOPADHYAY, SUHRID SANKAR (2017). Frontline: India's National Magazine. $<$ https://frontline.thehindu.com/arts-and-culture/rays-alter-ego/article9711308.ece> accessed 6 January 2021.

CHOWDHURY, INDIRA (1998). The Frail Hero and Virile History: Gender and the Politics of Culture in Colonial Bengal, New Delhi: Oxford University Press.

CHOWDHURY, SAYANDEB (2015). “Ageless Hero, Sexless Man: A Possible Pre-History and Three Hypotheses on Satyajit Ray's Feluda", South Asian Review, Vol. 36, No. 1, 109-130. https://doi.org/10.1080/02759527.2015.11933006 accessed 6 January 2021.

"Culture: Bengal" (2019). SFE: The Encyclopedia of Science Fiction. <http://www.sfenclyclopedia.com/archives/bengal/179288> accessed 2 May 2019.

DEY, PROVASH RONJAN (1978). Children's Literature of Bengal, Kolkata: Academy for Documentation and Research on Children's Literature.

FERRALL, CHARLES AND ANNA JACKSON (2010). Juvenile Literature and British Society, 1850-1950: The Age of Adolescence, London: Routledge.

GANGOPADHYAY, GARGI (2012). Reading Leisure: A Print Culture for Children in Colonial Bengal, Jadavpur University, Doctoral thesis. $<$ http://hdl.handle.net/10603/142702> accessed 7 March 2019. 
GHOSH, CHILKA (2016). "Mythologies of Childhood: Bengali Juvenile Magazines of the Last Two Decades", In: Züleyha Çetiner-Öktem (ed). Mythmaking Across Boundaries, London: Cambridge Scholars Publishing: 114-131.

KUTZER, DAPHNE M. (2000). Empire's Children: Empire and Imperialism in Classic British Children's Book, New York: Garland Publishing Inc.

MITRA, ROHINI (2010). "Bengali Adventure Stories", Arcanum. $<$ http://rohinimitra.blogspot.com/2010/08/bengali-adventure-stories.html?m=1> accessed 7 March 2019.

MUKHERJEE, ANUPARNA (2018). “Masculinity and 'Mute' Females in Bengali Children's Fiction", Ethos Literary Journal, Vol. 6, n.p. $<$ https://www.ethosliterary.org/november-2018/nonfiction/masculinity-and-mutefemales-in-bengali-childrens-fiction> accessed 7 Mar. 2019.

RAY, SATYAJIT (1979). Hatyapuri, Kolkata: Ananda Publishers, 1981.

--- (1974). Kailashey Kelengkari, Kolkata: Ananda Publishers.

ROY, GAUTAM CHANDO (2018). "Science for Children in a Colonial Context: Bengali Juvenile Magazines, 1883-1923", BJHS: Themes, Vol. 3, 43-72. https://doi.org/10.1017/bjt.2018.6 accessed 7 March 2019.

ROY, HEMENDRA KUMAR (1933). Abar Jaker Dhan: Kumar-Bimaler Adventure, Kolkata: Dev Sahitya Kutir Pvt. Ltd., 2001.

--- (1924). Jaker Dhan: Hemendra Kumar Roy Rachanabali 1 (The Hemendra Kumar Roy Omnibus, 1), Kolkata: Asia Publishing Co., 1984.

SARKAR. HARENDRA K. (1923). Heroes of Bengal, Kolkata: Kamala Book Depot Ltd.

SINHA, MRINALINI (1995). Colonial Masculinities: The Manly Englishman and the Effeminate Bengali in the Late Nineteenth Century, Manchester: Manchester University Press.

SMITH. MICHELLE J. (2011). Empire in British Girls' Literature and Culture: Imperial Girls, 1880-1915, London: Palgrave Macmillan.

Stella Chitralekha Biswas is a PhD candidate in Comparative Literature \& Translation Studies at the Central University of Gujarat. Her research interests include gender studies, sexuality archives, colonial archives, juvenile literature, speculative fiction and pedagogical discourses. 